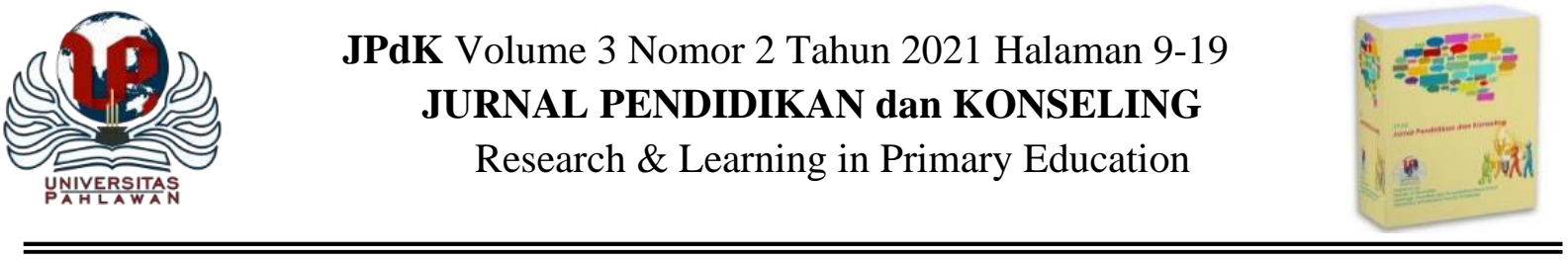

\title{
Pendidikan Hukum dan Pendidikan Nilai dalam Mewujudkan Warga Negara yang B aik dan Cerdas melalui Pendidikan Kewarganegaraan
}

\author{
Patricia Bunga Juwita Galand ${ }^{1}$, Dinie Anggraeni Dewi ${ }^{2}$ \\ Program Studi Pendidikan Guru Sekolah Dasar \\ Fakultas Keguruan dan Ilmu Pendidikan \\ Universitas Pendidikan Indonesia \\ Email: patriciabunga@upi.edu ${ }^{1}$,dinieanggraenidewi@upi.edu²
}

\begin{abstract}
Abstrak
Pendidikan kewarganegaraan berpartisipasi dalam mencapai salah satu tujuan penelitian sosial pendidikan yang mencapai tujuan pendidikan negara dan tujuan nasional pendidikan kehidupan bangsa melalui system Pendidikan nasional yang disahkan oleh Undang-Undang Dasar Negara Republik Indonesia. Pendidikan kewarganegaraan sebagai pendidikan hukum yang menunjukkan bahwa hukum dan hal-hal terkait termasuk di dalamnya pendidikan kewarganegaraan, karena pendidikan nilai berarti mencakup pendidikan nilai yang memungkinkan warga negara untuk memahami dan bertindak sesuai dengan nilai-nilai hukum. Nilai hukum berasal dari tempat kesadaran moral, begitu pula nilai hukumnya Nilai moral bersumber dari nilai ideologis dan landasan negara Pancasila karena Persyaratan hukum yang baik, hal ini dinilai dari pertimbangan moral. Pendidikan nilai dan pendidikan hukum akan membantu warga negara. Menjadi warga negara yang baik dan cerdas (smart and good citizen).
\end{abstract}

Kata Kunci: Pendidikan Kewarganegaraan, cerdas, warga negara yang baik

\begin{abstract}
Citizenship education participates in achieving one of the objectives of social education research which achieves the goals of state education and the national goals of education for the life of the nation through the national education system which is ratified by the Constitution of the Republic of Indonesia. Citizenship education as legal education shows that law and related matters include civic education, because value education includes value education that enables citizens to understand and act in accordance with legal values. Legal values come from a place of moral awareness, as well as legal values. Moral values come from ideological values and the state foundation of Pancasila because good legal requirements are judged from moral considerations. Values education and legal education will help citizens. To be a smart and good citizen.
\end{abstract}

Key Words: Civic education, smart, good citizen. 


\section{PENDAHULUAN}

Formalnya suatu pendidikan dapat dilihat dari perjalanan sejarah suatu bangsa. Pendidikan formal Indonesia memiliki sejarah yang secara tradisional sudah dipersiapkan melalui salah satu tugas dari beberapa tugasnya yaitu warga negara yang disiapkan untuk mencapai satu cita-cita nasional melalui disiplin ilmu sosial dalam suatu kurikulum yang telah dicetuskan.

Lahirnya berbagai nama sebutan untuk Pendidikan kewarganegaraan adalah salah satu upaya dari jalannya dan berkembangnya pasang surut perjalanan suatu politik bangsa. Juga dengan lahirnya berbagai kebijakan dalam bidang pendidikan ini lah menunjukan suatu bentuk tindak lanjut isi dari Dekrit Presiden 1959 khususnya dalam pendidikan kewarganegaraan untuk beralih kembali pada UUD 1945, diantara isinya adalah permintaan intruksi untuk melakukan pembaharuan terhadap buku-buku di Perguruan Tinggi.

Berkaitan dengan itu, salah satu hal untuk menyempurnakan Pendidikan ialah menciptakan jiwa pengertian dari patriotism di dalam hati siswa. Karena itu, pemerintah menyatakan bahwa panitia yang terdiri dari tujuh orang melalui Dep. PP dan K, Surat keputusan No. 122274/S, tanggal 10 Desember 1959 mengenai pembuatan buku pedoman kewajiban-kewajiban dan hak-hak warga negara Indonesia yang disertai dengan hal-hal yang akan mereka kaji tentang sebab adanya sejarah dan tujuan dari Revolusi kemerdekaan Indonesia.

Hasil dari panitia tersebut adalah buku Manusia dan Masyarakat Baru Indonesia (Civics) 1962. Buku tersebut menyatakan bahwa istilah Jerman "Staatsburgerkunde", Istilah Inggris "Civics", dan Indonesia
"Kewarganegaraan". Namun, penamaan manusia dan masyarakat baru Indonesia ini disebabkan karena kajian yang dikaji dalam buku ini sangat luas. Pedoman Pendidikan Kewarganegaraan yang dibukukan tersebut berisikan kesejarahan mengenai perjalanan dan perjuangan rakyat Indonesia, UUD 1945, terciptanya Pancasila, demokrasi terpimpin dan ekonomi Indonesia, konferensi Asia-Afrika, manifesto politik, kewajiban dan hak warganegara, pidato Presiden Soekarno, lampiran-lampiran tentang Dekrit Presiden, panca wardhana atau lima perkembangan, dan Declaration of Human Rights.

Sejak tahun 1959 bahan pembelajaran kewarganegaraan pada dasarnya telah digunakan sampai adanya perpecahan G30SPKI, oleh karena itu PKI dan paham komunisme serta semua ormas yang berkaitan dengannya ditetapkan sebagai partai terlarang, dan semua kegiatan dari partai terlarang adalah illegal. Atas usul Menteri Kehakiman, Mr.Sahardjo mengubah bahan Pendidikan kewarganegaraan 1959 menjadi kewarganegaraan dan itu berlaku sampai terciptanya kurikulum 1968.

Menurut kurikulum 1968, pendidikan kewarganegaraan berada sebanding dengan kelompok pembinaan jiwa Pancasila, bahan pembelajaraan yang digunakan sesuai dengan ketetapan pendidikan warga negara kurikulum 1975 yang dinamakan Pendidikan Moral Pancasila atau PMP. Pendidikan Moral Pancasila didtetapkan sebagai studi untuk Pendidikan kewarganegaraan dengan tujuan pembentukan warganegara yang pancasilais, beriman, bertaqwa, dan taat kepada Tuhan yang Maha Esa.

Sepanjang masa orde baru, telah terjadi perubahan kurikulum beberapa kali, dan jika kurikulum berubah, otomatis terjadi pula perubahan pada kurikulum Pendidikan kewarganegaraan dari kurikulum 1962 ke 
kurikukulum 1968 selanjutnya beralih ke kurikulum 1975, selanjutnya kurikulum 1984, dan terakhir kurikulum 1994. Kemudian kurikulum tahun 1994 ini dilengkapi dengan Edisi Revisi atau Kurikulum Suplemen 1994.

Dalam orde baru perubahan Pendidikan Kewargaan Negara (PKN) menjadi Pendidikan Moral Pancasila (PMP), kemudian PMP berubah lagi menjadi Pendidikan dan Kewarganegaraan (PPKn), semua perubahan ini terjadi secara terus menerus pada masa orde baru. Adanya perubahan atas penamaan Pendidikan Moral Pancasila (PMP) menjadi Pendidikan Pancasila dan Kewarganegaraan (PPKn) didasari oleh dua hal atau dua pertimbangan.

Pertimbangan pertama adalah kata moral dalam PMP dianggap oleh guru memberi beban psikologis yang cukup berat jika dilihat dari proses di lapangannya yang selalu menjadi kambing hitam jika ada ketersimpangan perilaku siswa yang tidak sesuai dengan dasar-dasar dan kaidah moral. Dan perubahan yang kedua adalah perubahan yang didasari oleh aspek legal pada Pasal 39 ayat 2 UU No. 2 Tahun 1989 mengenai Sistem Pendidikan Nasional, dengan pasal yang berbunyi "Isi kurikulum setiap jenis, jalur, dan jenjang Pendidikan wajib memuat Pendidikan Pancasila, Pendidikan kewarganegaraan dan penndidikan agama".

Berdasarkan sejarah mengenai keadaan kegentingan di masa lalu, jelas menunjukan betapa rapuh dan lemahnya suatu pembangunan, termasuk pembinaan terhadap warga negara yang hanya mengandalkan faktor ekonomi, faktor teknologi, atau faktor keamanan belaka dan tanpa memikirkan sungguh-sungguh mengenai setiap individuindividu warga negara sebagai sumber daya manusia. Sumber daya manusa disini memiliki artian yang akan terlibat pada keseluruhan sistem yang dibentuk dengan berbagai pendekatan.
Secara nyata pendekatan-pendekatan yang dilakukan demi pembangunan bangsa dan warga negara menunjukan kegagalan - kegagalannya, terutama pada kemajuan dan perkembangan bangsa dalam masyarakat yang saling menghargai, damai, demokratis, memiliki sikap toleransi, disiplin dan mematuhi aturanaturan hukum dan ketentuan yang berlaku. Kaitan diatas, mendorong Indonesia untuk melakukan pembahasan kembali mengenai Pendidikan kewarganegaraan yang memiliki hubungan sebagai pendidikan nilai dan pendidikan hukum guna menciptakan warga negara Indonesia yang cerdas dan baik (Smart and Good Citizen).

\section{METODOLOGI PENELITIAN}

Tempat dan waktu penelitian sebenarnya tidak dilakukan di satu tempat. Ini bukan waktu yang pasti, karena dalam studi ini tidak merupakan hasil dari penelitian di suatu lingkungan, tetapi berdasarkan penelitian sastra dan menganalisis fenomena keberadaan masyarakat yang umumnya mampu membentuk karakter kewarganegaraan melalui analisis penggalian data menggunakan penelitian literatur untuk mendapatkan informasi literatur jurnal, buku dan penelitian ilmiah terkait analisis lebih lanjut. Penelitian ini sering disebut penelitian non-eksperimen karena penelitian ini tidak mengontrol dan memanipulasi variabel penelitian dengan metode deskriptif, penelitian memungkinkan untuk menjalin hubungan antar variabel dan menguji hipotesis, dan menggunakan teori yang valid.

Pendidikan Kewarganegaraan atau Civic Education memiliki banyak pengertian dan istilah. Pendidikan kewarganegaraan dan Ilmu kewarganegaraan mengkaji hubungan manusia dengan perkumpulan-perkumpulan yang terorganisasi yaitu organisasi sosial, ekonomi, dan politik. Civic juga selalu dikaitkan dengan studi pemerintahan dan kewarganegaraan 
mengenai kewajiban, hak, dan hak-hak istimewa warga negara. Pasal 37 ayat 2 Undang-Undang Nomor 20 Tahun 2003 tentang Sistem Pendidikan Nasional menyatakan bahwa Kurikulum Pendidikan tinggi wajib memiliki cakupan Pendidikan agama, bahasa, dan Pendidikan kewarganegaraan. Berdasarkan pasal tersebut dapat disimpulkan bahwa Pendidikan kewarganegaraan merupakan Pendidikan ilmu yang bertujuan untuk membangun, mengembangkan, menanamkan nilai-nilai kebangsaan dan rasa cinta tanah air sesuai dengan dasar negara yaitu Pancasila.

Pendidikan Kewarganegaraan seperti Lahirnya masyarakat dan warga negara yang demokrasi, beriman dan bertaqwa kepada Tuhan yang Maha Esa, mengetahui hak dan kewajiban sebagai warga negara, dan melaksanakan aturanaturan yang berlaku dalam penuh kesadaran dan tanggung jawab demi dapat menciptakan keputusan secara cepat dan tepat baik untuk orang lain maupun untuk diri sendiri. Dilihat dari pernyataan tersebut dapat disimpulkan bahwa karakteristik Pendidikan kewarganegaraan pada dasarnya tetap di dalam pembelajaran yang tidak lepas dari pengamalan nilai-nilai kewarganegaraan terhadap bangsa dan negara. Juga berdasarkan kurkulum 2013, siswa juga diarahkan agar mengaktualisasikan diri secara optimal baik dari penilaian pengetahuan, sikap dan keterampilan, agar dapat menciptakan generasi dengan pribadi yang good and smart citizen.

Materi pendidikan pada dasarnya kewarganegaraan dari sumber daya berkembang. Meliputi ilmu sosial, humaniora, teknologi, budaya dan seni, bahkan nilai-nilai agama, dan masalah sosial dari lingkungan keluarga, masyarakat lokal, nasional dan internasional. Dalam metode pendidikan PKN harus perhatikan unsur filosofi pendidikan, psikologi pendidikan, dan terutama teori pembelajaran aktif bagi karyawan. Guru PKN memiliki kemampuan menjadi "direktur Belajar" atau seorang konduktor yang membentuk PKN yang "terintegrasi" (L 2019).

\section{HASIL PEENLITIAN DAN PEMBAHASAN}

Pendidikan Kewarganegaraan Di Indonesia, pengertian dan konsep dari Pendidikan kewarganegaraan tidak pernah terlepass dari ilmu kewarganegaraan atau perkembangan civics negara di Amerika Serikat, karena Amerika Serikat merupakan negara asal pelajaran civic education atau civics. Pembahasan civics mengenai Government tidak pernah terlepas dan selalu dikaitkan dengan pembahsan civic education. Juga sering kita jumpai istilah civic, citizenship, ataupun civic education dalam literatur studi sosial.

Kesepakatan yang dihasilkan dari konferensi MenteriPendidikan negara-negara berpenduduk besar di Delhi tahun 1996 menyatakan bahwa Pendidikan abad 21 harus mempersiapkan halhal yang diantara lain: 1. Mempersiapkan pribadi anggota masyarakat dan warga negara yang bertanggung jawab 2. Kesejahteraan manusia dan kelestarian hidup berdasarkan penanaman dasar pembangunan berkelanjutan (suistainable development) 3. Penyelenggaraan Pendidikan yang berorientasi pada pengembangan, penyebaran ilmu pengetahuan, penguasaan, seni dan teknologi demi kepentingan masyarakat atau warga negara.

Arti Pendidikan sangat penting untuk dipahami agar kita bisa mengembangkan Pendidikan kewarganegaraan. Menurut UU No. 2/1989 mengenai fungsi jurusan Pendidikan kewarganegaraan dan ilmu kewarganegaraan. Pada Pasal 37 ayat 2 UU No. 20 Tahun 2003, Pasal mengenai Sistem Pendidikan Nasional menyatakan bahwa kurikulum di Perguruan 
Tinggi wajib memuat Pendidikan kewarganegaraan, seperti yang sudah ditetapkan di dalam Surat Keputusan Direktorat Jenderal Pendidikan Tinggi Departemen Pendidikan Nasional No. 34/Dikti/Kep/2006 mengenai rambu-rambu pelaksanaan mata kuliah terhadap pengembangan kepribadian di Perguruan Tinggi dengan tujuan kompetensi yang professional dan memiliki rasa cinta dan bangga terhadap bangsa dan tanah air, menciptakan warga negara yang memiliki rasa daya saing tinggi, disiplin, demokratis berkeadaban, dan berpartisipasi secara aktif dalam kontribusi membangun dan menciptakan kehidupan yang damai sesuai dengan sistem nilai Pancasila.

Secara timbal balik, warga negara dan negara akan saling berhubungan dalam cakupan yang cukup luas dalam artian hampir keselurhannya kegiatan dasar manusia berkaitan dengan bidang dan kegiatan politik, hukum, keamanan dan ketertiban, ekonomi, komunikasi dan transportasi, kesehatan, dan nilai-nilai keagamaan dan kesenian. Dalam tujuan Pendidikan IPS, Pendidikan kewarganegaraan ini menekankan nilai-nilai guna menumbuhkan kewarganegaraan yang baik dan patriotism dalam membela negaranya. Maka bisa disebutkan bahwa pengertian dari Pendidikan kewarganegaraan adalah adaptasi maupun seleksi dari disiplin ilmu-ilmu sosial,ilmu humaniora, ilmu teknologi, ilmu agama, ilmu kewarganegaraan, dan ilmu dasar manusia lainnya yang disajikan dan diorganisir secara ilmiah dan psikologis untuk berkontribusi dalam tujuan Pendidikan nasional. Dengan adanya latar belakang antara pengertian ilmu kewarganegaraan dengan Pendidikan kewarganegaraan dapat dirangkum perbedaan dan persamaan antar keduanya sebagai berikut :

1. Ilmu kewarganegaraan a. Ilmu kewarganegaraan merupakan sub-sub disiplin ilmu politik yang dikaji secara ilmiah dengan tujuan memperkaya struktur disiplin ilmu politik.

b. Tingkat kesungkaran ilmu di Universitas merupakan tingkat kesungkaran ilmu pengetahuan kewarganegaraan.

c. Fakta-fakta, konsep, generalisasi, teori dan hukum merupakan permulaan dari tingkat kesungkaran ilmu kewarganegaraan.

d. Melalui proses wawancara, berhipotesis, mengumpulkan data, teori hukum, dan meyimpulkan generalisasi ilmu kewarganegaraan dikembangkan.

2. Pendidikan kewarganegaraan

a. Pendidikan kewarganegaraan adalah salah satu bagian dan tujuan dari Pendidikan Ilmu Pengetahuan Sosial yang berisikan disiplin ilmu, ilmu sosial, dokumen negara, Pancasila, humaniora, UUD 1945, dan perundangan negara, itu semua bekaitan dengan tekanan bahan Pendidikan terhadap hubungan warga negara dan berkenaan dengan bela negara. Seleksi adaptasi dari berbagai disiplin ilmu, ilmu sosial, Pancasila, humaniora, UUD 1945, dan dokumen negara lainnya yang dikaji secara psikologis dan ilmiah sebagai tujuan Pendidikan nasional.

b. Pendidikan kewarganegaraan dikembangkan secara psikologis dan secara ilmiah untuk tingkat khusus jurusan PPKN, namun juga harus dikembangkan penerapannya pada tingkat Pendidikan dasar dan menengah serta perguruan tinggi sesuai dengan pasal $39 \mathrm{UU}$ No.2/1989 mengenai sistem Pendidikan nasional.

c. Dalam pengembangan dan pelaksanaan Pendidikan kewarganegaraan kita harus memiliki cara fikir yang integratif dengan program Pendidikan yang terdiri dari unsur tujuan Pendidikan, bahan Pendidikan, 
metode Pendidikan, dan evaluasi Pendidikan.

\section{Pendidikan Hukum Melalui Pendidikan Kewarganegaraan}

Pendidikan hukum secara langsung berlangsung di perguruan tinggi. Fakultasfakultas hukum di Indonesia sedang mempersiapkan mahasiswanya menjadi pejabat pemerintah, hakim dan jaksa, pejabat kehakiman, dan advokat atau anggota dari profesi bebas. Dari pemberian pengajaran susunan dan isi kurikulum dapat kita simpulkan bahwa Pendidikan kewarganegaraan ini memiliki tujuan antara lain adalah untuk mempersiapkan orang kelak menjadi orang yang mempunyai kemahiran khusus dalam bidang hukum untuk menerapkan hukum yang berlaku di Indonesia dan sesuai dengan ketentuan-ketentuan yang ada di Indonesia.

Namun Pendidikan hukum tidak hanya bertujuan hanya untuk mempersiapkan orangorang yang mahir dalam hukum, namun Pendidikan hukum juga bertujuan untuk membantu masyarakat menerapkan budidaya taat hukum. Attitudinal problem atau masalah sikap orang disangkut pautkan dengan Pendidikan hukum dengan alasan keanggotaan masyarakat yang sedang membangun, jadi selain kurikulum dan isi kita perlu juga sesekali memerhatikan cara-cara atau pelaksanaan pengajaran dan penerapan hukum.

Pendidikan hukum melalui Pendidikan kewarganegaraan di dalamnya terdapat materi hukum maupun hal-hal yang berkaitan dengan hukum yang memuat dalam Pendidikan kewarganegaraan seperti pembahasan peraturan perundang-undangan, perubahan menuju arah demokratisasi dan pendewasaan pada bangsa yang berdaulat mempunyai kepercayaan dan jati diri bangsa harus dibenahi melalui strategi dan konsep perkembangan Pendidikan kewarganegaraan sebagai Pendidikan hukum.

Pendidikan hukum (Suparman, 2011, hlm. 46) merupakan suatu proses yang dilakukan secara sadar, baik formal maupun non formal dalam rangka mempertahankan, memperbaiki, meningkatkan kualitas hukum seseorang secara berencana dan terarah. Pernyataan tersebut di atas senada dengan pendapat G.E Langemeijer (Soekanto, 1993, hlm. 22) bahwa pendidikan hukum erat kaitannya dengan pembentukan kesadaran hukum. Beliau menyatakan bahwa tahap tentang kesadaran hukum sebetulnya berkisar pada pikiran-pikiran yang menganggap bahwa kesadaraan dalam diri warga masyarakat merupakan suatu faktor yang menentukan bagi sahnya hukum.

\section{Pendidikan Nilai Melalui Pendidikan Kewarganegaraan}

Pendidikan nilai bisa juga disebut dengan pendidikan moral karena sebagian besar membahas hal mengenai moralitas. Moralitas ini ditekankan melalui metode-metode pertimbangan moral dengan tujuan membantu mempersiapkan generasi yang memahami apa yang menjadi dasar suatu nilai. Dan salah satu objek dari Pendidikan moral adalah nilai. Nilai bisa kita artikan sebagai segala sesuatu yang berharga.

Nilai secara umum dapat dibedakann menjadi 2, yaitu nilai actual dan nilai ideal. Nilai ideal merupakan nilai yang dijadikan cita-cita bagi semua orang. Sedangkan nilai actual diartikan sebagai niai yang diekspresikan dalam kegiatan ataupun perilaku seseorang sehari- hari. Logika, etika, estetika, hukum, agama ataupun religious juga bisa dikategorikan sebagai bentuk nilai. Nilai bisa juga dijadikan sebagai sistem keyakinan diri ataupun acuan diri dalam kehidupan. Nilai memiliki dua sifat, yaitu ada 
nilai yang tidak berubah dan ada juga nilai yang bersifat berlaku bagi universal. Adapula nilai yang disebut dengan nilai subjektif, nilai subjektif merupakan nilai yang memiliki ketergantungan dengan kebudayaan, waktu dan tempat.

Secara umum pengertian nilai ialah standar atau patokan pola-pola pilihan kehidupan yang dapat mengarahkan ataupun membimbing seseorang ke arah yang benar. Nilai-nilai moral berpusat pada hati Nurani dan nilai moral tersebut tentunya harus dikembangkan melalui moral education atau Pendidikan moral, character education atau Pendidikan karakter, value education atau Pendidikan nilai.Uraian diatas menunjukan bahwa Pendidikan kewarganegaraan termasuk kedalam Pendidikan nilai.

Karena Pendidikan kewarganegaraan juga memuat kaidah moralitas yang bertujuan menciptakan warganegara yang dapat memahami dan berperilaku sesuai dengan nilai-nilai hukum. Pancasila erat kaitannya dengan pendidikan umum, khususnya tentang pendidikan kewarganegaraan. Pancasila dan UUD 1945 sebagai dasar pendidikan Negara memiliki beberapa arti. Secara filosofis, pendidikan nasional adalah Keniscayaan sistem nilai yang terkandung dalam Pancasila. Pendidikan substantif untuk mencapai tujuan pendidikan nasional sesuai dengan UU No 20 tahun 2003 tentang sistem pendidikan nasional.

Pancasila dan UUD 1945 merupakan perwujudan proses pembelajaran Prestasi pendidikan sosial dan politik yang di kembangkan anggota masyarakat, konstituen negara, dan warga negara yang cerdas dalam rangka mewujudkan visi berbangsa dan bernegara Indonesia melalui pendidikan kewarganegaraan, Pancasila biasanya dianggap sebagai tujuan terwujudnya konsep ideal warga negara Indonesia yang cerdas, terampil, dan berkarakter yang diamanatkan oleh Pnacasila dan UUD 1945. Pemetaan yang dilakukan Kalidjernih (2007) juga menunjukan bahwa fokus PKn di Indonesia pada tahun 1964, 1968, 1975, 1984, dan 1994 adalah pembentukan manusia Pancasila (Aji 2018).

Sampai saat ini Pendidikan Kewarganegaraan sudah menjadi bagian inheren dari instrumentasi serta praksis pendidikan nasional untuk mencerdaskan kehidupan bangsa Indonesia melalui koridor "value-based education".Konfigurasi atau kerangka sistemik Pendidikan Kewarganegaraan dibangun atas dasar paradigma sebagai berikut: Pendidikan kewarganegaraan secara kurikuler dirancang sebagai subjek pembelajaran yang bertujuan untuk mengembangkan potensi individu agar menjadi warga Negara Indonesia yang berakhlak mulia, cerdas, partisipatif, dan bertanggungjawab.

Pendidikan kewarganegaraan secara teoretik dirancang sebagai subjek pembelajaran yang memuat dimensidimensi kognitif, afektif, dan psikomotorik yang bersifat konfluen atau saling terintegrasi dalam konteks substansi ide, nilai, konsep, dan moral pancasila, kewarganegaraan yang demokratis, dan bela negara. Pendidikan kewarganegaraan secara programatik dirancang sebagai subjek pembelajaran yang menekankan pada isi yang mengusung nilai-nilai dan pengalaman belajar dalam bentuk berbagai perilaku yang perlu diwujudkan dalam kehidupan seharihari dan merupakan tuntunan hidup bagi warga Negara dalam kehidupan bermasyarakat, berbangsa dan bernegara (Juliardi 2015).

Dalam era globalisasi yang dipenuhi dengan persaingan ilmu pengetahuan dan teknologi, pendidikan nilai melalui materi PKn diperlukan guna menangkal kesemrawutan (chaos - menurut 
John Brigss dan David Peat) krisis multidimensional. Manusia memerlukan kematangan moral dan intelektual, kecerdasan intelektual dalam mengkitisi berbagai wacana pemikiran yang muncul di permukaan, kematangan emosional untuk dapat hidup kooperatif sekaligus kompetitif yang didasarkan atas jalinan sosial yang harmonis dan kematangan spiritual sebagai perwujudan ikatan transedental antara dirinya dengan sang pencipta.

Kematangan tersebut dilatih, diajar dan didik melalui PKn dengan model pendidikan berbasis nilai. (Ine Kusuma \& Markum Susatim, 2010: 38) Dengan adanya perubahan yang dapat terjadi secara nasional, maupun internasional, maka pendidikan kewarganegaraan memiliki peran yang penting untuk memperkuat rasa identitas nasional setiap bangsa agar tidak dengan mudah terbawa arus perubahan yang terjadi. Diprediksi bahwa model pendidikan kewarganegaraan yang sekarang ada tidak akan cukup digunakan untuk menghadapi tantangan yang muncul di era global.

Hal tersebut juga senada dengan yang disebutkan oleh Aqib (2012: 40) menyebutkan bahwa berdasarkan kajian nilainilai agama, norma-norma sosial, peraturan/hukum, etika akademik, dan prinsip-prinsip HAM, telah teridentifikasi butir-butir nilai yang dikelompokkan menjadi nilai utama, yaitu nilainilai perilaku manusia dalam hubungannya dengan Tuhan Yang Maha Esa, diri sendiri, sesama manusia, dan lingkungan serta kebangsaan.

Adapun secara rinci nilai-nilai tersebut adalah: 1) Hubungannya dengan Tuhan, yaitu religius. Pikiran, perkataan, dan tindakan seseorang yang diupayakan selalu berdasarkan pada nilai-nilai Ketuhanan dan/atau ajaran agamanya. 2) Hubungannya dengan diri sendiri, yaitu jujur, bertanggung jawab, bergaya hidup sehat, disiplin, kerja keras, percaya diri, berjiwa wirausaha, berpikir logis, kritis, kreatif, dan inovatif, mandiri, ingin tahu, cinta ilmu 3) Hubungannya dengan sesama, yaitu sadar akan hak dan kewajiban diri dan orang lain, patuh pada aturan-aturan sosial, menghargai karya dan prestasi orang lain, santun, demokratis. 4) Hubungan dengan lingkungan, yaitu peduli akan sosial dan lingkungan ditunjukkan dengan sikap dan tindakan selalu berupaya mencegah kerusakan pada lingkungan alam sekitarnya, dan mengembangkan upaya-upaya untuk memperbaiki kerusakan alam yang sudah terjadi dan selalu ingin memberi bantuan bagi orang lain dan masyarakat yang membutuhkan. 5) Nilai kebangsaan, yaitu nasionalis dan menghargai keberagaman (Dianti 2016).

Menurut Wahab dan Sapriya (2011: 315), dalam sistem pengembangan kurikulum tingkat satuan pendidikan saat ini, tujuan PKn mengacu pada standar isi mata pelajaran PKn sebagaimana yang tercantum dalam lampiran Permendiknas nomor 22/2006. Tujuan PKn untuk jenjang SD, SMP, Dan SMA tidak berbeda. Semuanya berorientasi pada pengembangan kemampuan/ kompetensi peserta didik yang disesuaikan dengan tingkat perkembangan kejiwaan dan intelektual, emosional, dan sosialnya.

Secara rinci, mata pelajaran Pendidikan Kewarganegaraan bertujuan agar peserta didik memiliki kemampuan sebagai berikut: 1) Berpikir secara kritis, rasional, dan kreatif dalam menanggapi isu kewarganegaraan. 2) Berpartisipasi secara aktif dan bertanggung jawab, dan bertindak secara cerdas dalam kegiatan bermasyarakat, berbangsa, dan bernegara, serta anti-korupsi. 3) Berkembang secara positif dan demokratis untuk membentuk diri berdasarkan karakterkarakter masyarakat Indonesia agar dapat hidup bersama dengan bangsa-bangsa lainnya. 4) Berinteraksi dengan 
bangsabangsa lain dalam percaturan dunia secara langsung atau tidak langsung dengan memanfaatkan teknologi informasi dan komunikasi (Pangalila 2017).

Indonesia masuk dalam kategori Exlusive karena pendidikan kewarganegaraan hanya menjadi sarana utama dalam mendidik warganegara di Indonesia dan tidak melibatkan unsur-unsur lain. Padahal pendidikan kewarganegaraan juga bisa di masukan dalam program lain di ekstra kulrikuler hingga program-program pendidikan kemasyarakatan seperti melalui ogranisasi masyarakat, dan melalui kegiatan masyarakat. Selain itu pendidikan kewarganegaraan di indonesia juga masih terkesan formal bentuk pengajaranya, dan terikat oleh isi materi semata. Sehingga lebih mudah untuk melakukan penilaian karena hanya menitikberatkan pada aspek pengetahuan (Winataputra \&Budimansyah, 2012). Pengajaran pendidikan kewarganegaraan di Indonesia termasuk dalam Civic Education, bukan pada Citizenship Education.

Dalam konteksnya Citizenship Education memiliki makna yang lebih luas dari pada Civic Education. John C. Cogan (1999:4) mengartikan civic education sebagai mata pelajaran di sekolah yang dirancang untuk mempersiapkan warga muda untuk dapat berperan aktif dalam komunitas mereka ketika kelak mereka dewasa" (Cogan, 1999:4). Dalam hal ini Cogan membedakannya dengan Citizenship Education, yang menurut cogan lebih luas maknanya dari pada Civic Education karena mencakup pengalaman di sekolah (Pembelajaran formal) maupun di luar sekolah (Pembelajaran informal). Sehingga dalam Citizenship Education mencakup pembelajaran/ pengalaman kewarganegaraan yang diperoleh dari organisasi keagamaan, organisasi masyarakat, media masa, dan dari keluarga. Sehingga dapat dipahami bahwa citizenship education dapat dimaknai lebih luas dari pada Civic education. Di Indonesia konteks belajar pendidikan kewargan hanya sebatas pengajaran yang ada di sekolah (formal).

Indonesia belum mampu mengoptimalkan pendidikan kewarganegaraan dalam ranah di luar sekolah (informal) sekaligus didalam sekolah. Beberapa contoh pendidikan kewarganegaraan yang di anggap mendekati kontinum maksimal yakni di negara-negara di wilayah eropa tengah, utara, selatan serta di Amerika (Mustikarini and Feriandi 2020).

Penanaman nilai inti pendidikan karakter bertujuan untuk menghidupkan kembali karakter warga negara yang sesuai dengan nilai-nilai Pancasila. Antara lain nilai ketaqwaan, keimanan, kejujuran, kepedulian, hingga nilai etika dan sopan santun. Sekolah merupakan salah satu sarana yang tepat untuk menanamkan nilai inti pendidikan karakter yang berlandaskan Pancasila kepada peserta didik. Karena penanaman nilai inti pendidikan karakter pada dasarnya untuk menciptakan peserta didik menjadi warga negara yang demokratis dan berkarakter sesuai dengan nilai-nilai Pancasila (Zahrudin, Ismail, and Hasanah 2020).

\section{SIMPULAN}

Pendidikan Kewarganegaraan atau Civic Education memiliki banyak pengertian dan istilah. Pendidikan kewarganegaraan dan Ilmu kewarganegaraan mengkaji hubungan manusia dengan perkumpulan-perkumpulan yang terorganisasi yaitu organisasi sosial, ekonomi, dan politik. karakteristik Pendidikan kewarganegaraan pada dasarnya tetap di dalam pembelajran yang tidak lepas dari pengamalan nilai- nilai kewarganegaraan terhadap bangsa dan negara. 
Pendidikan kewarganegaraan adalah suatu bentuk usaha sebagai bekal pengetahuan dan kemampuan dasar bagi peserta didik dan tentunya berkaitan dengan hubungan antar warga dan negara serta pendahuluan Pendidikan bela negara agar terwujudnya warga negara yang dapat diandalkan oleh negara dan bangsa. Pendidikan kewarganegaraan termasuk kedalam Pendidikan nilai. Karena Pendidikan kewarganegaraan juga memuat kaidah moralitas yang bertujuan menciptakan warganegara yang dapat memahami dan berperilaku sesuai dengan nilai-nilai hukum.

Oleh karena itu harus ada tindakan tegas pada pemerintah terhadap perangkatnya untuk terus meningkatkan konsep maupun manejerial Pendidikan kewarganegaraan sehingga di hari yang akan datang tujuan Pendidikan kewarganegaraan dapat tercapai. kewarganegaraan seperti pembahasan peraturan perundang-undangan, perubahan menuju arah demokratisasi dan pendewasaan pada bangsa yang berdaulat mempunyai kepercayaan dan jati diri bangsa harus dibenahi melalui strategi dan konsep perkembangan Pendidikan kewarganegaraan sebagai Pendidikan hukum.

Pendidikan hukum melalui Pendidikan kewarganegaraan di dalamnya terdapat materi hukum maupun hal-hal yang berkaitan dengan hukum yang memuat dalam Pendidikan Pendidikan kewarganegaraan termasuk kedalam Pendidikan nilai. Karena Pendidikan kewarganegaraan juga memuat kaidah moralitas yang bertujuan menciptakan warganegara yang dapat memahami dan berperilaku sesuai dengan nilai-nilai hukum.

\section{DAFTAR PUSTAKA}

A, Muhammad Abror, Nunuk Suryani, and Deni Tri Ardianto. 2019. "Pendidikan Kewarganegaraan (Citizenship) Sebagai Sarana Mewujudkan Warga Negara Yang
Beradab (Good Citizenship)." Seminar Nasional Pendidikan Pengembangan Kualitas: 69.

Ahmad Jamalong, dkk. (2019). Pendidikan Pancasila dan Kewarganegaraan di Perguruan Tinggi. Depok: PT RajaGrafindo Persada.

Aji, Purnomo Cahyo. 2018. "Peran PKN Dalam Membentuk Karakter Kewarganegaraan Melalui Pendekatan Berbasis Nilai Di Perguruan Tinggi.": 3. https://ppkn.fkip.uns.ac.id/wpcontent/uploa ds/2018/08/Purnomo-Aji.- UniversitasSebelas-Maret..pdf.

Baginda, Mardiah. 2018. "Nilai-Nilai Pendidikan Berbasis Karakter Pada Pendidikan Dasar Dan Menengah.” Jurnal Ilmiah Iqra' 10(2): 10.

Belladonna, Aprillio Poppy. 2018. "Strengthening Citizenship Education as Legal Education in Higher Education." ournal of National Awareness Civil Society 4(2): 114-15.

Budi Juliardi. (2016). Pendidikan Kewarganegaraan Untuk Perguruan Tinggi. Depok: Rajawali Pers.

Dianti, Puspa. 2016. "Integrasi Pendidikan Karakter Dalam Pembelajaran Pendidikan Kewarganegaraan Untuk Mengembangkan Karakter Siswa." Jurnal Pendidikan Ilmu Sosial 23(1): 62.

Juliardi, Budi. 2015. "Implementasi Pendidikan Karakter Melalui Pendidikan Kewarganegaraan." jurnal Bhinneka Tunggal Ika 2(2): 124-25. https://ejournal.unsri.ac.id/index.php/jb ti/article/download/4581/pdf.

L, Suradi. 2019. "Pendidikan Kewarganegaraan Sebagai Pendidikan Nilai Dan Pendidikan Hukum Dalam Mewujudkan Warga Negara Yang Cerdas Dan Baik (Smart and Good Citizen)." Jurnal Pemikiran dan Penelitian Ilmu-ilmu Sosial, Hukum, \& Pengajarannya XIV (2): 115-16. 
L. Suradi. (2019). Pendidikan Kewarganegaraan Sebagai Pendidikan Nilai dan Pendidikan Hukum dalam Mewujudkan Negara yang Cerdas dan Baik. Dalam Journal Online Volume XIV (2).

Mardenis. (2019). Pendidikan Kewarganegaraan dalam Rangka Pengembangan Kepribadian Bangsa. Depok: PT Raja Grafindo Persada.

Mustikarini, Indriyana Dwi, and Yoga Ardian Feriandi. 2020. "Konfigurasi Pendidikan Kewarganegaraan Ekologi Perspektif Social Culture." Jurnal Pancasila Dan Kewarganegaraan 5(2): 56-57.

Octavia, Erna, and M. Anawar Rube'i. 2017. "Penguatan Pendidikan Karakter Berbasis Pancasila Untuk Membentuk Mahasiswa Prodi PPKN Menjadi Warga Negara Yang Baik Dan Cerdas. ”Jurnal Pendidikan Sosial 4(1):

114.

http://journal.ikippgriptk.ac.id/index.ph $\mathrm{p} / \mathrm{sosial} /$ article/view/427.

Pangalila, Theodorus. 2017. "PENINGKATAN CIVIC DISPOSITION SISWA MELALUI PEMBELAJARAN PENDIDIKAN KEWARGANEGARAAN (PKn)." Jurnal Pendidikan Kewarganegaraan, Universitas Lambung Mangkurat 7(1): 93.

Ubaedillah. (2016). Pendidikan Kewarganegaraan (Civic Education) Pancasila, Demokrasi dan Pencegahan Korupsi. Jakarta: Prenadamedia Group.

Zahrudin, Ma'mun, Shalahudin Ismail, and Aan Hasanah. 2020. "PENANAMAN NILAI INTI PENDIDIKAN KARAKTER BERLANDASKAN PANCASILA PADA PESERTA DIDIK DI SEKOLAH." JPA 21: 170 